\title{
Synthesis of $\mathrm{Pr}_{0.70} \mathrm{Sr}_{0.30} \mathrm{MnO}_{3 \pm \delta}$ and $\mathrm{Nd}_{0.70} \mathrm{Sr}_{0.30} \mathrm{MnO}_{3 \pm \delta}$ Powders by Solution-Combustion Technique
}

\author{
Reinaldo Azevedo Vargas*, Everton Bonturim, Rubens Chiba, \\ Marco Andreoli, Emília Satoshi Miymaru Seo \\ Instituto de Pesquisas Energéticas e Nucleares - IPEN-CNEN/SP, \\ Centro de Ciência e Tecnologia de Materiais - CCTM, \\ CEP 05508-000, São Paulo, SP, Brasil
}

Received: September 14, 2010; Revised: April 12, 2011

\begin{abstract}
Powders of $\mathrm{Pr}_{0.70} \mathrm{Sr}_{0.30} \mathrm{MnO}_{3 \pm \delta}$ (PSM) and $\mathrm{Nd}_{0.70} \mathrm{Sr}_{0.30} \mathrm{MnO}_{3 \pm \delta}$ (NSM) compositions are being investigated as alternative cathode materials for Intermediate Temperature Solid Oxide Fuel Cells. The compositions were synthesized by a solution-combustion method using metal nitrates and urea as fuel. Combustion synthesis is a highly suitable synthesis route for achieving fine and homogeneous powders at low temperatures. Single phase pseudo-perovskite was obtained by X-ray diffraction after heat treatment of PSM and NSM powders at $900{ }^{\circ} \mathrm{C}$. The synthesized and milling powders had an average particle size between 0.27 to $0.07 \mu \mathrm{m}$. Chemical analyses of the powders calcined was performed by X-ray fluorescence and morphological analysis by scanning electron microscopy. The results were compared with literature values, indicating characteristics adjusted for preparation of ceramic suspensions.
\end{abstract}

Keywords: combustion synthesis, powders, cathode, solid oxide fuel cell

\section{Introduction}

Solid Oxide Fuel Cells (SOFC) has been identified as clean, efficient and high capacity promissory alternative energy devices. They have demonstrated high-energy conversion efficiency, high power density, extremely low pollution, as well as flexibility with other hydrocarbon fuels ${ }^{(1-3)}$.

A major obstacle for commercial applications of SOFC is still the high costs of both materials and processing ${ }^{(1-2)}$. Thus, Intermediate Temperature Solid Oxide Fuel Cells (ITSOFC), which can significantly reduce the costs of SOFC is also being studied ${ }^{(4-6)}$.

This instigates research in the area of new ceramic powder synthesis to cathode, anode, interconnector or electrolyte materials used in this technology. A number of approaches such as solid-state reaction, sol-gel, hydrothermal, spray-drying, freeze-drying, coprecipitation, polymer precursor and solution-combustion have been used for ceramic powder preparation and processing ${ }^{(7,8)}$.

In addition, solution-combustion has been utilized for the synthesis of various oxide powders such as ferrites, chromites, manganites, NiYSZ cermet, zirconates, doped ceria, hexa-aluminates, pyrochlores, and oxide phosphors, among others ${ }^{(3,7)}$. An amino acid such as glycine is commonly used as fuel for the combustion process. However, urea, citric acid, oxylydihydrazide, and sucrose have also been recently utilized as complexing agents and fuel for combustion synthesis ${ }^{(9,10)}$.

A simple solution-combustion process is an attractive synthetic route particularly for the preparation of multicomponent oxide materials, since the homogeneity of the aqueous solution of the salts is preserved in the combustion residue. This process is also unique as all the reactants are mixed in solution at the molecular level resulting in homogeneous reaction products and faster reaction rates ${ }^{(9-13)}$.

In the present study, strontium-doped praseodymium manganite $\left(\mathrm{Pr}_{1-\mathrm{x}} \mathrm{Sr}_{\mathrm{x}} \mathrm{MnO}_{3 \pm \delta}-\mathrm{PSM}\right)$ and strontium-doped neodymium manganite
$\left(\mathrm{Nd}_{1-\mathrm{x}} \mathrm{Sr}_{\mathrm{x}} \mathrm{MnO}_{3+\delta}-\mathrm{NSM}\right)$, both with $\mathrm{x} \approx 0.3$, cathode powders were synthesized using the urea-nitrate solution-combustion technique ${ }^{(4-6)}$ due to its high-energy efficiency, fast heating rates, short reaction times, and high reaction temperatures. The objective of this study was to synthesize fine powders of PSM and NSM compositions for future preparation of ceramic suspensions for applications as ITSOFC alternative cathodes.

\section{Experimental}

\subsection{Powder synthesis}

The manganite-based ceramics were synthesized by combustion reactions by employed Aldrich hydrate nitrate salts, $\operatorname{Pr}\left(\mathrm{NO}_{3}\right)_{3} \cdot 6 \mathrm{H}_{2} \mathrm{O}$ (99.9\% purity) and $\mathrm{Nd}\left(\mathrm{NO}_{3}\right)_{3} \cdot 6 \mathrm{H}_{2} \mathrm{O}(99.9 \%$ purity), Vetec nitrate salt $\mathrm{Sr}\left(\mathrm{NO}_{3}\right)_{2} \cdot\left(99 \%\right.$ purity) and Fluka nitrate salt $\mathrm{Mn}\left(\mathrm{NO}_{3}\right)_{2} \cdot 4 \mathrm{H}_{2} \mathrm{O}(99 \%$ purity) as cation precursors, and Caal urea, $\mathrm{CO}\left(\mathrm{NH}_{2}\right)_{2}$, used as fuel. Distilled water was used for the preparation of solutions. The flow chart for the process is shown in Figure 1.

The stoichiometric composition of each mixture was calculated based on the total oxidizing and reducing valences of the oxidant and the fuel, in order to release the maximum energy for the reaction.

Metal nitrates are employed both as metal precursors and oxidizing agents. Stoichiometric amounts of the metal nitrates, to yield $10 \mathrm{~g}$ of the final PSM or NSM oxide powder, were dissolved in distilled water. The urea solution was slowly added to the metal nitrate aqueous solution under constant agitation. Urea acts as a complexing agent for metal cation of varying sizes due to its carboxylic group at one end and its amino group at the other. The complexation process increases the solubility of metal ions and helps to maintain homogeneity by preventing their selective precipitation. 


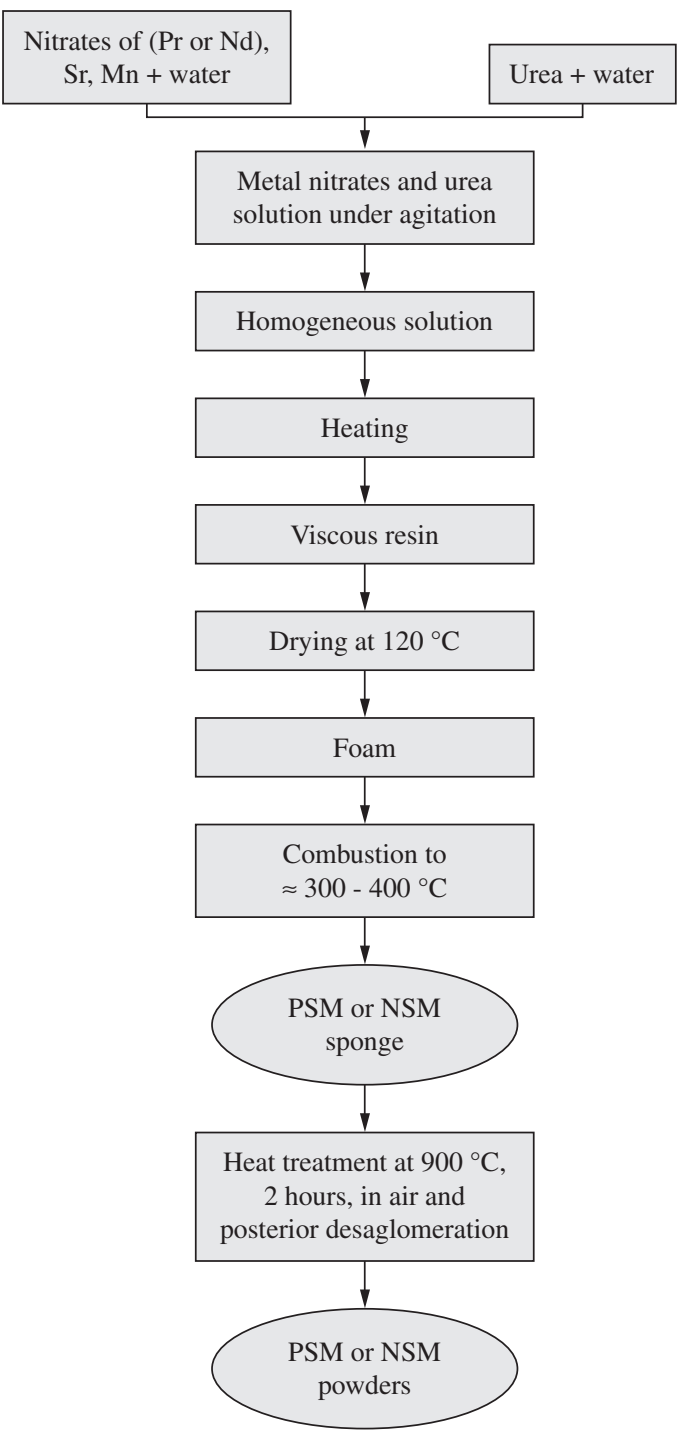

Figure 1. PSM and NSM powder flow chart for combustion synthesis.

The water in the solution quickly evaporates the resulting viscous liquid swelled, auto-ignited and initiated a highly exothermic selfcontained combustion process, converting the precursor materials into fine powders of the complex oxides. Urea acts as a fuel during the combustion reaction, being oxidized by the nitrate ions. Oxygen from the air does not play an important role during the combustion process. The overall combustion reactions can be represented as:

$$
\begin{aligned}
& 0.70 \mathrm{Pr}\left(\mathrm{NO}_{3}\right)_{3}+0.30 \mathrm{Sr}\left(\mathrm{NO}_{3}\right)_{2}+\mathrm{Mn}\left(\mathrm{NO}_{3}\right)_{2}+\mathrm{CO}\left(\mathrm{NH}_{2}\right)_{2} \rightarrow \\
& \operatorname{Pr}_{0.70} \mathrm{Sr}_{0.30} \mathrm{MnO}_{3 \pm \delta}+\mathrm{CO}_{2} \uparrow+\mathrm{N}_{2} \uparrow+\mathrm{H}_{2} \mathrm{O} \\
& 0.70 \mathrm{Nd}\left(\mathrm{NO}_{3}\right)_{3}+0.30 \mathrm{Sr}\left(\mathrm{NO}_{3}\right)_{2}+\mathrm{Mn}\left(\mathrm{NO}_{3}\right)_{2}+\mathrm{CO}\left(\mathrm{NH}_{2}\right)_{2} \rightarrow \\
& \mathrm{Nd}_{0.70} \mathrm{Sr}_{0.30} \mathrm{MnO}_{3 \pm \delta}+\mathrm{CO}_{2} \uparrow+\mathrm{N}_{2} \uparrow+\mathrm{H}_{2} \mathrm{O}
\end{aligned}
$$

The presented reactions indicate the formation of $\mathrm{CO}_{2}, \mathrm{~N}_{2}$, and $\mathrm{H}_{2} \mathrm{O}$ as gaseous products. The evolution of gases during the combustion process helps in the formation of a fine ceramic powder by limiting the inter-particle contact. The resulting black powder contained some carbon residue. It was calcined further to convert into the desired product.

The final treatments were calcined at $900{ }^{\circ} \mathrm{C}$ for 2 hours in air in order to increase the powder crystalline and to reduce carbon residue and then attrition-milled for 2 hours using $1 \mathrm{~mm}$ diameter zirconia balls in ethylic alcohol with a final sieving before characterization was performed. The experiments were directed for compounds attainment for $\mathrm{x}$ equal $30 \mathrm{~mol} \% \mathrm{Sr}$.

\subsection{Characterization}

X-ray diffraction analysis was carried out on powders in different molar relation oxidant-fuel (nitrates salts-urea) for crystalline phase identification. Powder XRD patterns were recorded at room temperature using a step scan procedure $\left(0.02^{\circ} / 2 \theta\right.$ step, time per step 0.5 or 1 second) in the $2 \theta$ range $20-80^{\circ}$ on a Rigaku Multiflex automated diffractometer equipped with a crystal monochromator employing $\mathrm{CuK} \alpha$ radiation. X-ray fluorescence spectroscopy was determined using a Shimadzu EDX900HS. The average agglomerate size was measured by means of a CILAS 1064 particle-size laser analyzer. Specific surface area of the powders was determined using a Micromeritics Analyzer 1330. Finally, agglomerate morphology was observed using a Philips XL30 scanning electron microscope.

\section{Results and Discussion}

The calculation, based in combustion reaction principle, utilized urea as combustible agent and (Pr or $\mathrm{Nd}$ ), $\mathrm{Sr}$, and $\mathrm{Mn}$ nitrates for PSM or NSM formation (14). However, XRD analysis (Figure 2) of the powders obtained after combustion shows phase perovskite formation for ions: urea mole ratio 1:5.

In combustion synthesis, metal nitrate-fuel mixture is heated to between 300 and $400{ }^{\circ} \mathrm{C}$ to initiate the combustion reaction. In auto ignition processes, the metal nitrate-urea mixture is first heated on a hot plate. The resulting charred powder is then heated in a muffle furnace at $900^{\circ} \mathrm{C}$ in order to remove carbon and to form the crystalline phase. The combustion synthesis process also produced amorphous powders and required further calcinations for pure phase formation.

The $\mathrm{Pr}$ or $\mathrm{Nd}$ and $\mathrm{Sr}$ concentrations used in this study were expected to result in an orthorhombic pseudo-perovskite structure. The Table 1 present the results obtained by X-ray diffraction. A comparison of our results against those reported by Kostogloudis et al. ${ }^{(6)}$ confirmed the formation of an orthorhombic pseudo-perovskite structure and presence of a small amount of praseodymium oxide $\left(\mathrm{Pr}_{2} \mathrm{O}_{3}\right)$ and neodymium oxide $\left(\mathrm{Nd}_{2} \mathrm{O}_{3}\right)$.

The lattice parameters were calculated with the Crystallographica Search Match program, which enabled the determination of lattice parameters using the existing JCPDS database for these materials, with their respective crystalline structures and spatial groups. The CELREF program was used to calculate the refinement of the lattice parameters of the PSM and NSM samples. The samples showed the presence of a small amount of $\operatorname{Pr}_{2} \mathrm{O}_{3}$ (JCPDS number 000-810820) and $\mathrm{Nd}_{2} \mathrm{O}_{3}$ (JCPDS number 000-86-1531); resulting from the incomplete combustion reaction.

The presence of $\mathrm{Pr}^{3+}$ or $\mathrm{Nd}^{3+}$ in the form of $\mathrm{Pr}_{2} \mathrm{O}_{3}$ or $\mathrm{Nd}_{2} \mathrm{O}_{3}$ is influenced by the ionic radius of the ion. The $\mathrm{Pr}^{3+}$ ion has an ionic radius of $0.990 \AA$ and $\mathrm{Nd}^{3+}$ ion has an ionic radius of $0.983 \AA$, while the ionic radius of the $\mathrm{Sr}^{2+}$ ion is $1.180 \AA$. Because the ionic radius of the $\mathrm{Sr}^{2+}$ ion is larger than $\mathrm{Pr}^{3+}$ or $\mathrm{Nd}^{3+}$ ions, there is a limitation and substitution these ions for $\mathrm{Sr}$ in the structures ${ }^{(15)}$.

In Figure 3, the spectrum obtained by XRD of PSM and NSM powders proves the importance of the calcination stage for secondary phase elimination and attainment of the PSM and NSM pure phase.

The results of X-ray fluorescence spectrometry (XRF) determined the molar values of constituent elements of the PSM and NSM powders. The concentrations values of the constituent elements of the initial composition were similar to the values of the synthesized composition obtained in this synthesis, as shown in Table 2. 

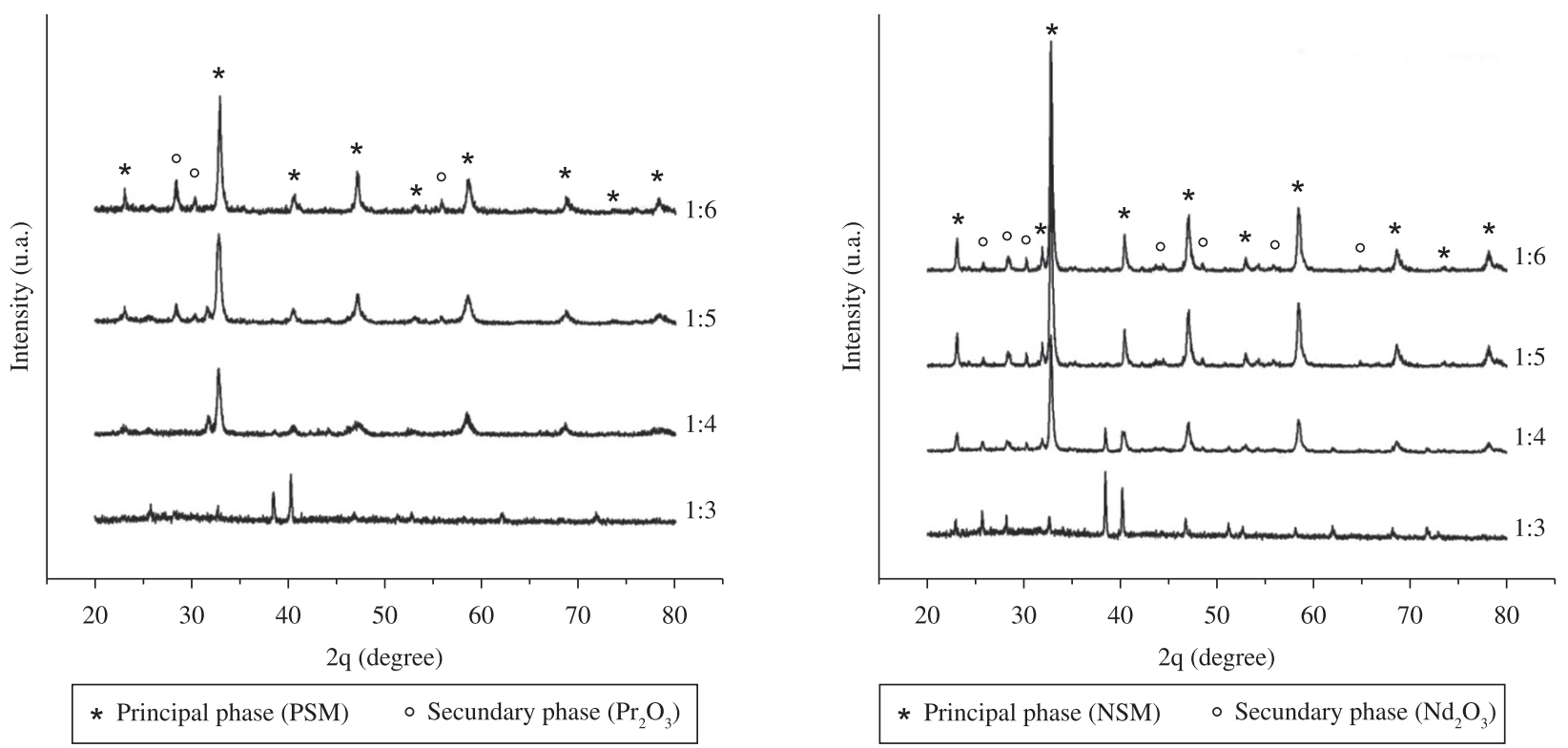

Figure 2. XRD pattern of powders obtained at various PSM (a) and NSM (b) ions: urea mole ratios (1:3; 1:4; $1: 5$ and 1:6) showing phase pure PSM formation at 1:5.

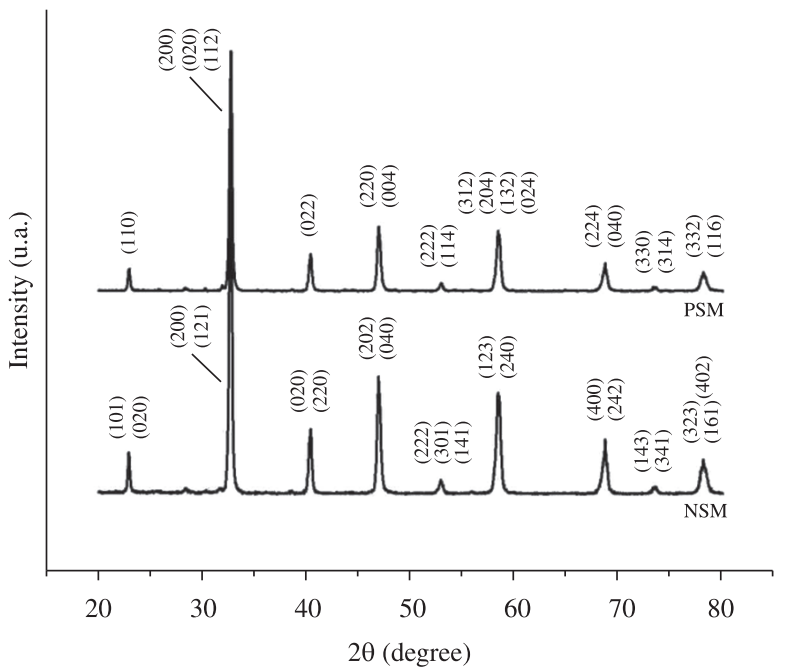

Figure 3. XRD pattern of PSM and NSM powders after calcination.

Table 1. Crystalline structure sand lattices of synthesized powder.

\begin{tabular}{ccccc}
\hline \multirow{2}{*}{ Powder } & Crystalline & \multicolumn{3}{c}{ Lattice parameters $(\AA)$} \\
\cline { 3 - 5 } & Structure & $\mathrm{a}$ & $\mathrm{b}$ & $\mathrm{c}$ \\
\hline PSM & Orthorhombic & 5.486 & 5.467 & 7.713 \\
NSM & Orthorhombic & 5.449 & 5.455 & 7.964 \\
\hline
\end{tabular}

Table 2. X-ray fluorescence spectroscopy of PSM and NSM samples.

\begin{tabular}{cccc}
\hline Sample & $\begin{array}{c}\text { Stoichiometric } \\
\text { composition }\end{array}$ & $\begin{array}{c}\text { Chemical elements } \\
\text { (Mass \%) }\end{array}$ & $\begin{array}{c}\text { Obtained } \\
\text { composition }\end{array}$ \\
\hline PSM & $\mathrm{Pr}_{0.70} \mathrm{Sr}_{0.30} \mathrm{MnO}_{3 \pm \delta}$ & $\mathrm{Pr}=34.98 \pm 0.08$ & $\mathrm{Pr}_{0.67} \mathrm{Sr}_{0.33} \mathrm{MnO}_{3 \pm \delta}$ \\
& & $\mathrm{Sr}=10.78 \pm 0.01$ & \\
& & $\mathrm{MnO}_{3}=54.25 \pm 0.07$ & \\
$\mathrm{NSM}$ & $\mathrm{Nd}_{0.70} \mathrm{Sr}_{0.30} \mathrm{MnO}_{3 \pm \delta}$ & $\mathrm{Nd}=37.24 \pm 0.07$ & $\mathrm{Nd}_{0.69} \mathrm{Sr}_{0.31} \mathrm{MnO}_{3 \pm \delta}$ \\
& \multicolumn{3}{c}{$\mathrm{Sr}=9.80 \pm 0.01$} \\
\\
\multicolumn{3}{c}{$\mathrm{MnO}_{3}=52.96 \pm 0.08$} \\
\hline
\end{tabular}

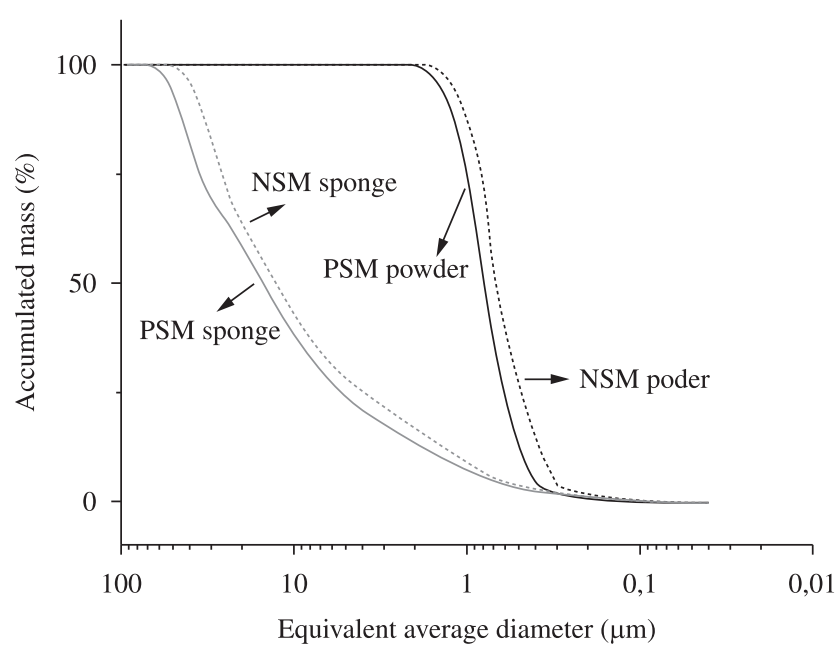

Figure 4. Equivalent average diameter of PSM and NSM samples without milling.

Table 3. Equivalent average diameter of PSM and NSM samples.

\begin{tabular}{cccccc}
\hline Sample & \multicolumn{3}{c}{ Equivalent average diameter $(\mu \mathrm{m})$} \\
\cline { 2 - 3 } & \multicolumn{2}{c}{ Without milling } & & \multicolumn{2}{c}{ Powder after milling } \\
\cline { 2 - 3 } \cline { 5 - 6 } & Sponge & Powder & & 2 hours & 4 hours \\
\hline PSM & 20.54 & 0.79 & & 0.27 & 0.08 \\
NSM & 15.85 & 0.67 & & 0.25 & 0.07 \\
\hline
\end{tabular}

The powders processed by attrition-milling of the ashes obtained at PSM or NSM ions: urea mole ratio 1:5 result in similar particle size distributions. The particle size observed was in the $0.2-0.8 \mu \mathrm{m}$ range. The average equivalent diameter $\left(D_{50}\right)$ values of the powders were in the 0.25 range for NSM and $0.27 \mu \mathrm{m}$ for PSM. Only a small fraction $(<10 \%)$ of particles are larger than $0.20 \mu \mathrm{m}$. Figure 4 shows the average equivalent diameter of PSM and NSM powder prepared at ions: urea mole ratio 1:5.

According to Figure 4, after the sponge desaglomeration in mortar, PSM and NSM powders acquire an inferior average equivalent 


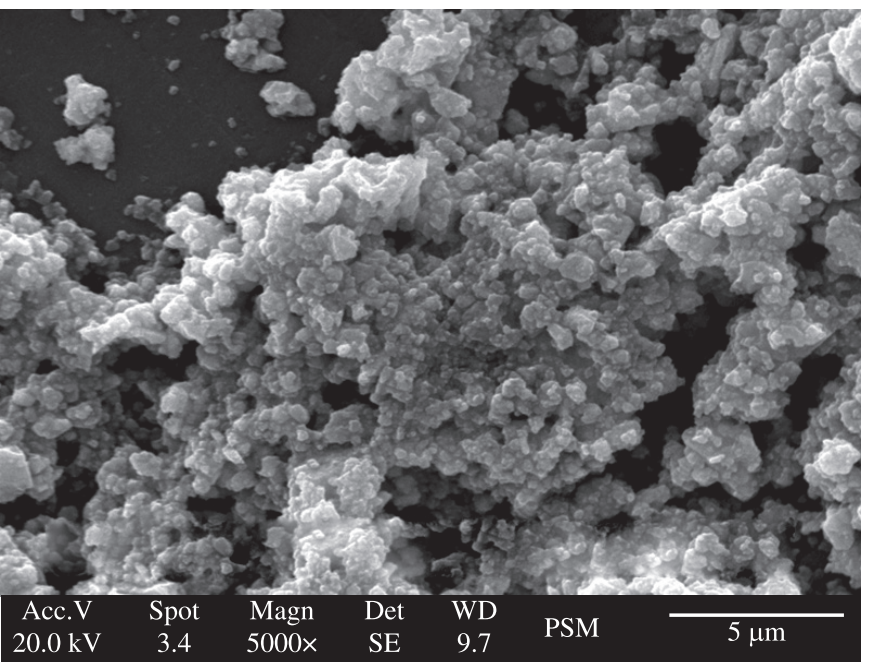

(a)

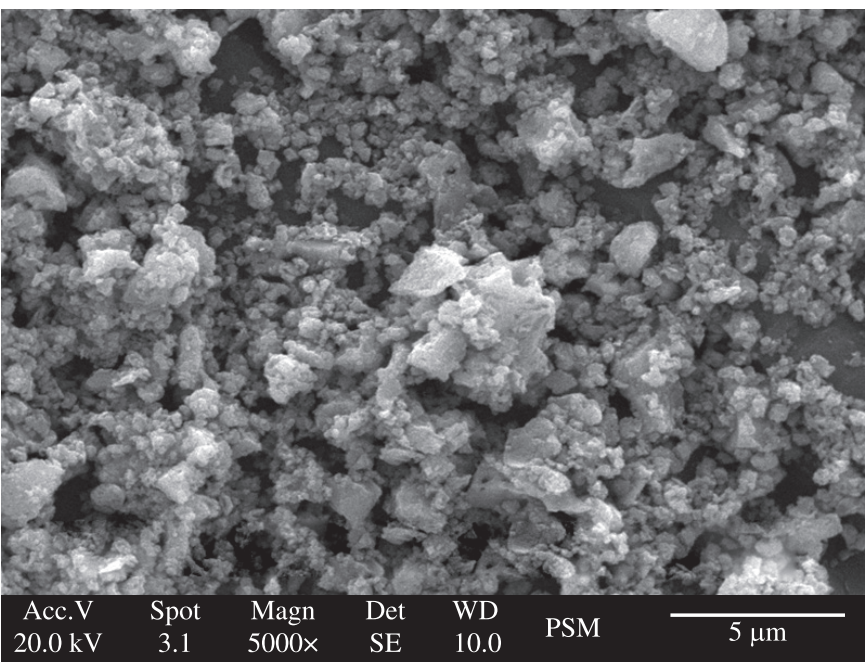

(b)

Figure 5. Scanning electron micrograph of PSM (a) and NSM (b) powders obtained by solution-combustion method

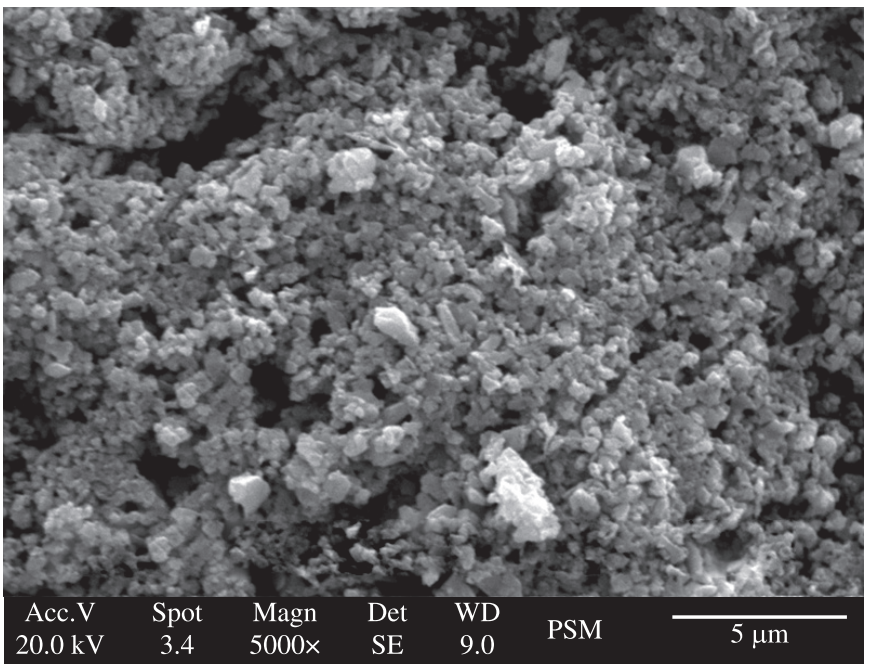

(a)

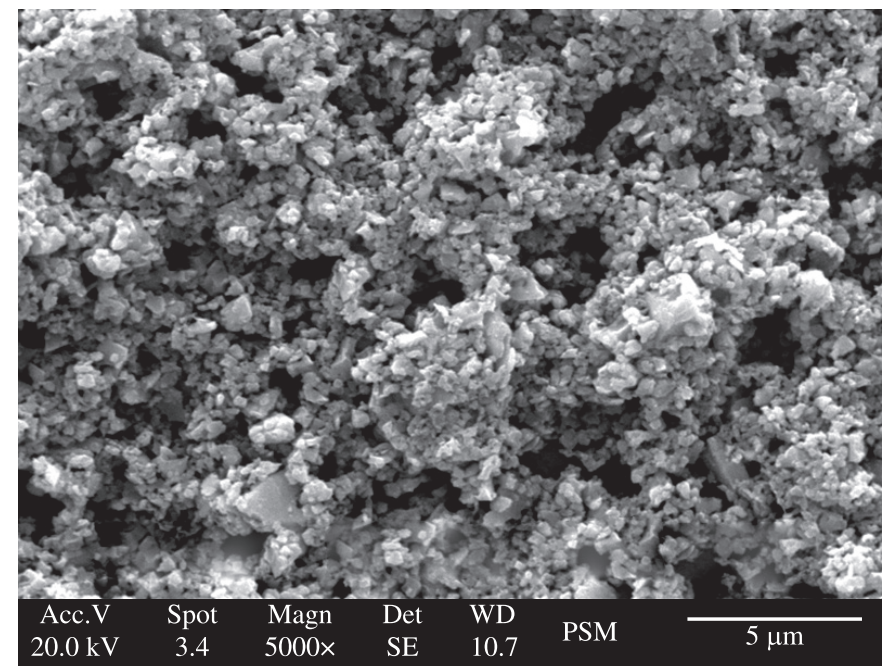

(b)

Figure 6. Scanning electron micrograph of PSM (a) and NSM (b) powders obtained by solution-combustion method after milling for 2 hours.

diameter of $1 \mu \mathrm{m}$. With a 2 hour attrition-milling, the particle size is reduced to $0.25 \mu \mathrm{m}$. Grinding for 2 more hours, reduces the particle size to $0.07 \mu \mathrm{m}(70 \mathrm{~nm})$. Millings over 4 hours do not significantly affect the results. Table 3 shows the equivalent average diameter of PSM and NSM powders prepared after the synthesis and milling stages.

In analysis by SEM were observed the particles morphology of PSM and NSM are agglomerates inferior at $1 \mu \mathrm{m}$ (Figures 5 and 6).

\section{Conclusions}

Powders of PSM and NSM cathode materials for intermediate temperature solid oxide fuel cells have been synthesized by the ureanitrate solution-combustion method. Formation of crystalline phases in both the powders started at relatively low temperatures. However, the synthesized powders had to be calcined at or above $900{ }^{\circ} \mathrm{C}$ and milled to yield phase-pure perovskite products.

The analyses by XRF revealed that the synthesis was efficient in the attainment of the PSM and NSM compositions, with values around stoichiometric calculated. The scanning electron micrograph revealed that particle sizes were agglomerates between 1-0.5 $\mu \mathrm{m}$. The
PSM and NSM powders observed by XRD, presented the formation of a main phase with ions: urea mole ratio 1:5 and identification of orthorhombic crystalline structure. The powders with average particle sizes inferior to $1 \mu \mathrm{m}$ were homogeneous and can be conveniently used by wet powder spraying on electrolyte substrate.

\section{Acknowledgments}

This study was supported by National Counsel of Technological and Scientific Development of Brazil - CNPq (Conselho Nacional de Desenvolvimento Científico e Tecnológico).

\section{References}

1. Nesaraj AS. Recent developments in solid oxide fuel cell technology - a review. Journal of Scientific \& Industrial Research. 2010; 69:169-176.

2. Minh NQ. Solid oxide fuel cell technology - features and applications. Solid State Ionics. 2004; 174(1/4):271-277. doi:10.1016/j.ssi.2004.07.042.

3. Seo ESM, Yoshito WK, Ussui V, Lazar DRR, Mello Castanho SRH and Paschoal JOA. Influence of the starting materials on performance of 
high temperature oxide fuel cells devices. Materials Research. 2004; 7:215-220. doi:10.1590/S1516-14392004000100029.

4. Zhu B. Advantages of intermediate temperature solid oxide fuel cells for stationary applications. Journal of Power Sources. 2001; 93:82-86. doi:10.1016/S0378-7753(00)00564-4.

5. Matínez JP, López DM, Morales JCR, Buergler BE, Núñez P and Gauckler LJ. Fuel cell studies of perovskite-type materials for IT-SOFC. Journal of Power Sources. 2006; 159:914-921. doi:10.1016/j.jpowsour.2005.11.036.

6. Kostogloudis GCH, Vasilakos $\mathrm{N}$ and Ftikos J. Preparation and characterization of $\operatorname{Pr} 1-x \operatorname{Sr} x \mathrm{MnO}_{3 \pm \delta}(x=0,0.15,0.3,0.4,0.5)$ as a potential $\mathrm{SOFC}$ cathode material operating at intermediate temperatures $\left(500-700^{\circ} \mathrm{C}\right)$. Journal of European Ceramic Society. 1997; 17(12):513-1521.

7. Reed JS. Principles of Ceramics Processing. 2th ed. New York: John Wiley \& Sons; 1995.

8. Sigmund WM, Bell NS and Bergström L. Novel Powder-Processing Methods for Advanced Ceramics. Journal of American Ceramic Society. 2000; 83:1557-1574. doi:10.1111/j.1151-2916.2000.tb01432.x.

9. Aruna ST, Muthuraman M and Patil KC. Combustion synthesis and properties of strontium substituted lanthanum manganites $\mathrm{La}_{1-\mathrm{x}} \mathrm{Sr}_{\mathrm{x}} \mathrm{MnO}_{3}$

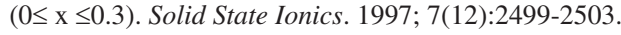

10. Setz LFG, Corrêa HPS, Paiva Santos CO and Mello Castanho SRH. Sintering of cobalt and strontium doped lanthanum chromite obtained by combustion synthesis. Materials Science Forum. 2006; 530/31:671-676.

11. Deshpande K, Muasyan A and Varma A. Aqueous combustion synthesis of strontium doped lanthanum chromite ceramics. Journal of American Ceramic Society. 2003; 86:1149-1154. doi:10.1111/j.1151-2916.2003. tb03439.x.

12. Juarez RE, Lamas DG, Lascalea GE and Walsoe De Reca NE. Syntheisis of nanocrystalline zirconia powders for TZP ceramics by nitrate citrate combustion route. Journal of European Ceramic Society. 2000; 20:133-138. doi:10.1016/S0955-2219(99)00146-6.

13. Breval E and Agrawal DK. Synthesis of (NZP)-structure type materials by the combustion reaction method. Journal of American Ceramic Society. 1998; 81:1729-1735. doi:10.1111/j.1151-2916.1998.tb02541.x.

14. Jain SR, Adiga KC and Vemeker VRP. A New Approach to Thermochemical Calculations of Condensed Fuel-Oxidizer Mixtures. Combustion and Flame. 1981; 40:71-79. doi:10.1016/0010-2180(81)90111-5.

15. Choi K-Y, Lemmens P, Guntherodt G, Pattabiraman M, Rangarajan G, Gnezdilov VP et al. Raman scattering study of $\mathrm{Nd}_{1}-x \operatorname{Sr} x \mathrm{MnO}_{3}(x=0.3$, 0.5). Journal of Physics: Condensed Matter. 2003; 15:3333-3342. doi:10.1088/0953-8984/15/19/332. 